p.122キネシオロジー的研究 体青 学 研 究 15-5

46. 施パワーのトレーニンケに明する研究

東京大学 猪阙道夫○金子公有，梅野克身

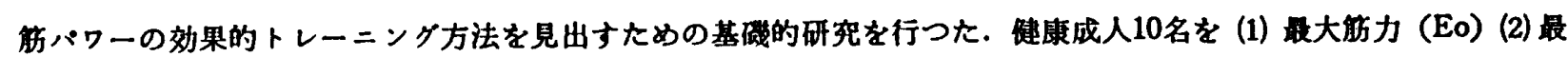

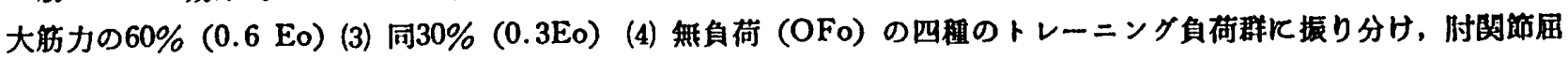

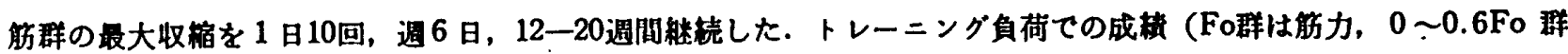

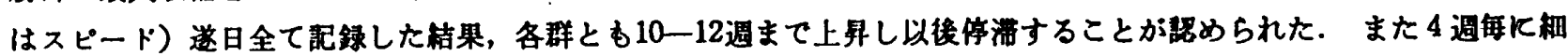

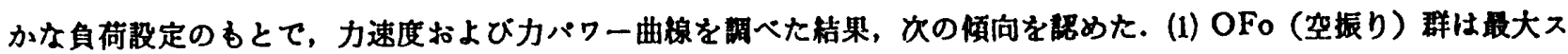

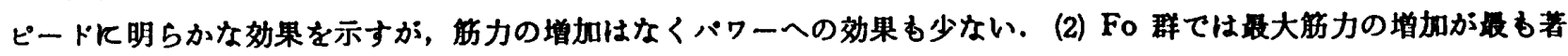

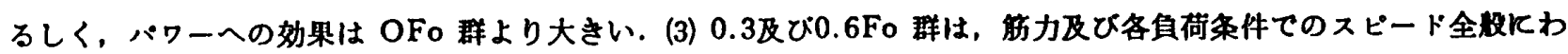

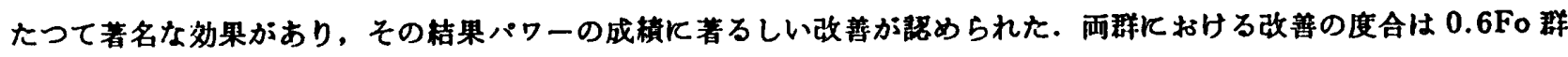

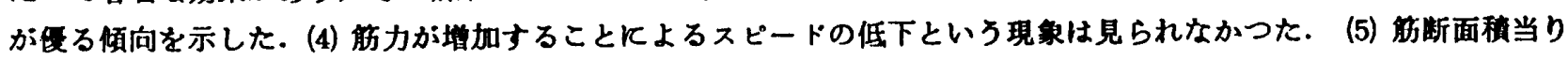
筋力の增加は，Fo 群と0.6Fo 群が（同水䒜で）他群より高く，筇断面当り最大パワーの增加は，0.6F。群Kおいて

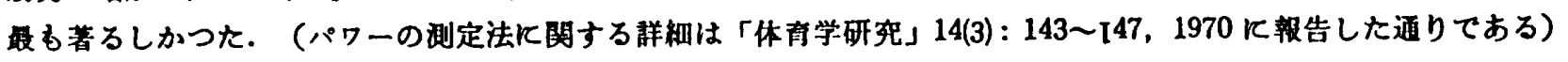

\title{
47. ボールのスピード
}

ボール投けの目的のうち，最も速いポールを投けることを目的として，その速度がポールの重量の荤いによつてど

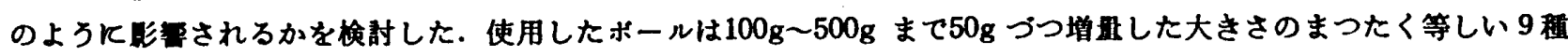
類でる、投球功作は野球のセットポシションから水平方向に最大の努力で投げた. 速度の测定にあたつては cds七

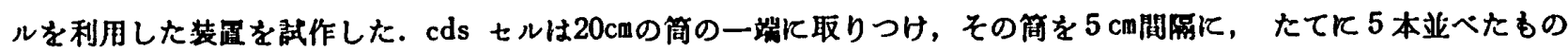

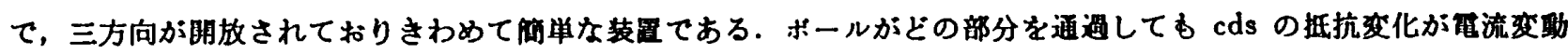

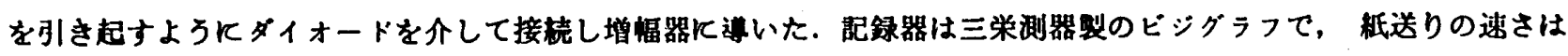
每秒100cmである. 被検者は成人男子 6 名である。

ボール投げといろ多関節を通して行われる全身逃動について，速度と負荷重五との関係をボールの速度とボールの

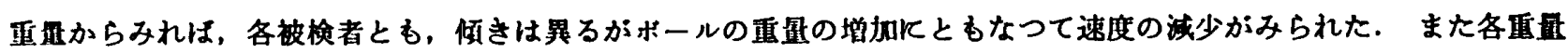
に対する仕事量をみれは，100g のボールて2 $25 \mathrm{~m} / \mathrm{sec}$ 前後の被検者では，ボールの重量が增すとつれて仕挑量は增加

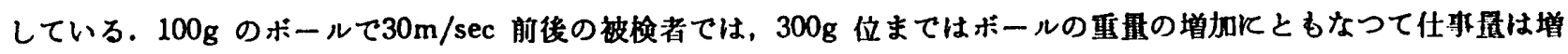
加するが, $350 \mathrm{~g} \sim 500 \mathrm{~g}$ Кかけて山がみられた.

\section{8. 投げにおけるスナツプのカ学的研究}

東京工業大学O植屋清見, 東京教商大学 淑川㑆二, 長崎大学 吉本信, 東京工柴大学 石田俊九,

桐生武夫，藤江学，水田拓道，松永尚久，藤怣公裕

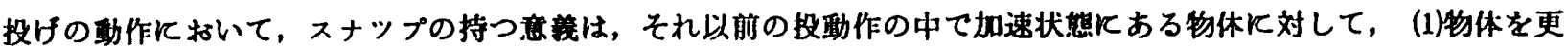
几加速する．(2)物体の投方向へのコントロールをする（3)回枟を与える等てあると思われる．本研究において，佨九

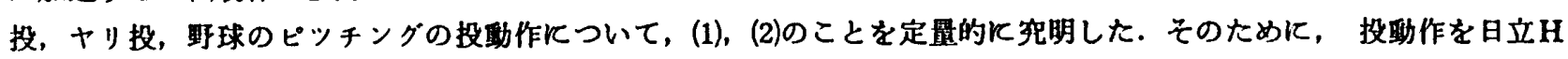

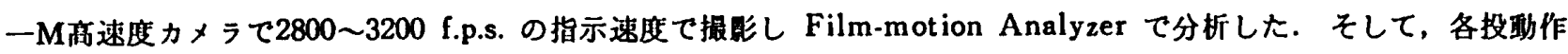

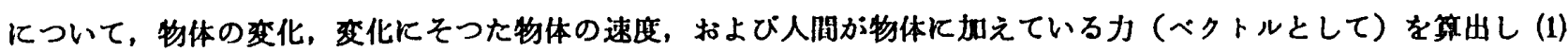
(2)の考察した J.W. Ban は人間は，物体を手首のスナップで大きく加速するためK大きな力を加えていると述へてい ろが，篚者等の研究ては，スナップて物作飞加える力は，それ程大きくなく，砲丸投， $18.20 \mathrm{~m}(\mathrm{n})$ で17kg（それ以

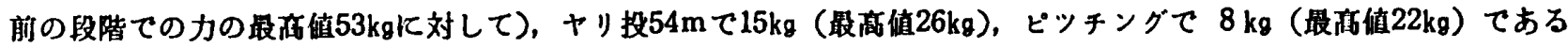
一方，手首のスナップによる物体の加速をみるために，手首と物体の相対進度をるると，砲丸投 $15.60 \mathrm{~m}$ (16P) て $5.1 \mathrm{~m} / \mathrm{s}, 18.20 \mathrm{~m}(12 \mathrm{P}) \tau 6.5 \mathrm{~m} / \mathrm{s}$, †リ投 $54 \mathrm{~m} \tau 5.0 \mathrm{~m} / \mathrm{s}, 18.20 \mathrm{~m}(12 \mathrm{P})$ ピッチングてとなり，傾向としては物体 の重些の小さい程手首による加速はあると思われるが，重腱の䢖いkよる差はそれ程ない，以上のことと，力をべ

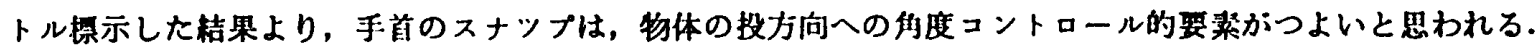

